\title{
エリスロマイシンの嗅覚障害に対する効果
}

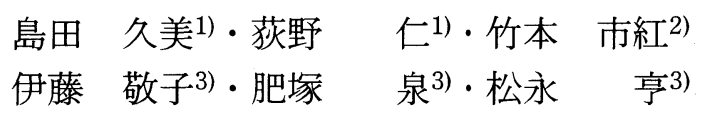

\section{Low-Dose Erythromycin Therapy for Olfactory Disorder in Patients with Chronic Paranasal Sinusitis}

\author{
Kumi Shimada and Hitoshi Ogino \\ (Otemae Hospital) \\ Ichiko Takemoto \\ (Izumisano City Hospital) \\ Noriko Ito, Izumi Koizuka and Toru Matsunaga \\ (Osaka University)
}

\begin{abstract}
Low-dose erythromycin (EM) therapy has been reported to be effective for chronic paranasal sinusitis, but olfactory disorder was not cured although nasal discharge and nasal obstruction showed a good response. In the present study, we examined the efficacy of lowdose EM therapy systematically in 24 patients with olfactory disorder caused by chronic paranasal sinusitis who were treated with 400 or $600 \mathrm{mg}$ of EM per day for 3 to 8 months. Eighteen patients showed clouded sinuses and/or obstruction of the olfactory cleft in the nose and paranasal sinus X-rays (Group S), and six patients showed no pathological findings in the radiological examination (Group $\mathrm{C}$ ). We measured the clouded area in the paranasal sinuses and the olfactory cleft before and after EM therapy. Subjective improvement of the olfactory disorder was noted in $79 \%$ and objective improvement of olfaction test (T\&T olfactogram) results was noted in $61 \%$ of Group $\mathrm{S}$ whereas the respective percentage in Group $\mathrm{C}$ were $0 \%$ and 16\%. The patients with improved olfaction showed widening of the olfactory cleft but no change of the clouded area in the paranasal sinuses. We conclude that the improvement of olfaction in patients with chronic paranasal sinusitis is due to effect of EM on the olfactory pathology.
\end{abstract}

Key words: low-dose erythromycin therapy, olfactory cleft, T\&T olfactogram

\section{はじめに}

慢性副鼻腔炎による嗅覚障害は, 鼻汁や鼻茸 により呼吸気道が閉塞されて起こる，いわゆる 呼吸性嗅覚障害が主な原因であると考えられる。
かつて我国で重要な鼻疾患であった慢性副鼻腔 炎は，生活環境の変化や抗生物質の発達により 軽症化しており，それに伴い，慢性副鼻腔炎を 原因とする呼吸性嗅覚障害も減少している。し

1）大手前病院耳鼻咽喉科

2) 市立泉佐野病院耳鼻咽搌科

3) 大阪大学医学部耳鼻咽喉科学教室 
かしながら，クオリティー・オブ・ライフの向 上を求める現代では，嗅覚障害に対する関心が 高まって扣り，慢性副鼻腔炎に上る呼吸性嗅覚 障害に対する治療は，今後もなお重要であると 思われる。

びまん性汎細気管支炎はかつて予後不良であ ったが，マクロライド系抗生物質であるエリス ロマイシンを少量長期投与することによって， 著しく改善されることが最近報告されてい

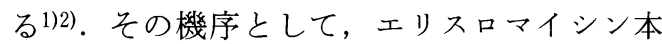
来の抗菌作用だけではなく，好中球やマクロフ ァージ等の炎症・免疫担当細胞に対する作用に よることが明らかになりつつある。エリスロマ イシンはこれらの細胞に高濃度に取り込まれ， その機能に影響を与えることにより，気道粘膜 の粘液・水分分泌抑制等の抗炎症作用を現し, 気道粘膜を正常化するためと考兄られてい る2) 5)。 また本剂は組織移行性, 特に呼吸器や 耳鼻・ 口腔隣接組織等への移行がきわめて良好 であり3)，慢性副鼻腔炎に対しても有用である ことが確かめられている6) 99. また，様々なエ リスロマイシン誘導体も同様に副鼻腔炎に対し て有効であるとの報告が多くなされている10) 12). しかし嗅覚障害に対する効果は，これらの報 告6)7110) 12) の中では鼻漏や鼻閉の改善度に 比し低值である。

今回我々は，慢性副鼻腔炎により生じた嗅覚 障害患者に対して，エリスロマイシンを少量長 期投与し，良好な成績を得たので報告を行う。

\section{対象と方法}

対象は，平成 4 年 1 月から平成 5 年 6 月の間 に, 大手前病院, 大阪大学医学部附属病院, 市
立泉佐野病院の耳鼻咽喉科嗅覚外来を訪れた嗅 覚障害患者24名である. そのらち18名は, 鼻X 線にて副鼻腔あるいは嗅裂部に陰影を認め, “慢 性副鼻腔炎”症例としてまとめた ( S 群)。残り 6 名は対照症例であり $(\mathrm{C}$ 群), 前鼻鏡検査, 嗅 裂部硬性鏡検査, 鼻 X線で嗅覚障害をきたし得 る所見を認めず，嗅粘膜より中枢性の嗅覚障害 と診断できた症例を選んだ.

投与方法は，エリスロマイシンを $400 \mathrm{mg}$ か ら $600 \mathrm{mg}$ 内服させ， 3 力月以上継続投与した. 併用薬は，無しあるいはLーシステイン製剤の みとした。

投与前と投与後に，それぞれ鼻 $\mathrm{X}$ 線 $(\mathrm{P} \rightarrow \mathrm{A}$ 法, Waters 法, 断層撮影) と $\mathrm{T} \& \mathrm{~T}$ オルファ クトグラムを行い，その効果を調べた。鼻X線 上での副鼻腔に対する効果を客観的に評価する ため, Waters 法による写真で上顎洞の陰影黒 化度を定量化した。測定方法は藤森ら10)の報 告に従い, 眼窩部黒化度 $(\mathrm{O}$ 値) と上顎洞黒化度 (M値)の比 $(\mathrm{M} / \mathrm{O}$ 比)を算出した。黒化度は, TOYO TDS- 400 で測定した。有意差検定に は， $\chi^{2}$ 検定を用いた。

\section{結果}

a . 患者背景

今回我々が検討を加えた症例の背景を表 1 亿 示した。罹病期間とは嗅覚障害が発症してから エリスロマイシン投与までの期間とした。

$\mathrm{S}$ 群の初診時の臨床所見を表 2 に示した。鼻 漏, 鼻閉等の鼻症状を有していた症例が13例あ ったが，症状は全例軽度であった。嗅覚障害の みの症例は 5 例であった。鼻腔所見では, 中鼻 道に鼻茸を認めた症例が 6 例あったが，それの

表 1 患者背景

\begin{tabular}{c|c|c}
\hline \hline & “慢性副車腔炎” 症例 & 対照症例 \\
\hline 症例数 男:女 & $7: 11$ & $3: 3$ \\
\hline 年齢 (平均) & $38 \sim 72(57.8)$ & $38 \sim 65(54.5)$ \\
\hline 罹病期間 & 2 力月 10年 & 2 力月 15年
\end{tabular}


みで呼吸性嗅覚障害を起こすと思われるほど大 きなものは認めなかった。鼻 $\mathrm{X}$ 線は, 通常の $\mathrm{P}$ $\rightarrow \mathrm{A}$ 法, Waters 法で, 副鼻腔陰影を読影し, 外眼角より $2 \mathrm{~cm}$ の断層撮影写真で, 嗅裂部の 開大，閉鎖を読影した。嗅裂部の閉鎖のみを認 めた症例が 4 例, 副鼻腔陰影のみが 5 例, 副鼻 腔と嗅裂部ともに陰影を認めた症例が 9 例であ った。

C 群では, 嗅覚障害以外に, 耳鼻咽喉科領域 に特記すべき所見がなく，原因疾患は感冒後が 3 例，頭部外傷後が 1 例，そして原因不明が 2 例であった。

前投薬は，S 群では，ステロイド剤の点鼻 4 例，L-システイン製剤内服 4 例，ビタミン剤

表 2 “慢性副鼻腔炎”症例の臨床所見

\begin{tabular}{|c|c|c|c|}
\hline \multicolumn{3}{|c|}{ m } & 症例数 $(\%)$ \\
\hline \multicolumn{3}{|c|}{ 蕃漏 · 後畺漏 } & $11 \quad(61)$ \\
\hline \multicolumn{3}{|c|}{ 鼻閉 } & $4 \quad(22)$ \\
\hline \multicolumn{3}{|c|}{ 嗅覚障害のみ } & $5 \quad(28)$ \\
\hline \multicolumn{3}{|c|}{ 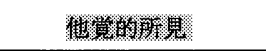 } & \\
\hline \multirow{4}{*}{\multicolumn{2}{|c|}{ 前鼻鏡検査 }} & 鼻茸 & $6 \quad(33)$ \\
\hline & & 下甲介腫脹 & $4 \quad(22)$ \\
\hline & & 鼻中隔弯曲 & $3(17)$ \\
\hline & & 正常 & $5(28)$ \\
\hline \multirow{3}{*}{ 鼻X線 } & \multicolumn{2}{|c|}{ 嗅裂部閉鎖のみ } & $4 \quad(22)$ \\
\hline & \multicolumn{2}{|c|}{ 副鼻腔陰影のみ } & $5 \quad(28)$ \\
\hline & \multicolumn{2}{|c|}{ 嗅裂部+副鼻腔 } & $9 \quad(50)$ \\
\hline
\end{tabular}

内服 1 例, 無し 8 例, 詳細不明 3 例であり, C 群では，ステロイド剤の点鼻 5 例， L-システ イン製剤の内服 1 例であった.

治療前の $\mathrm{T} \& \mathrm{~T}$ オルファクトグラムでは, 認知域值平均嗅力損失は両群ともに高度障害例 が多く，認知域值脱失症例は，S 群では 10 例 (56\%)，C群では 4 例(67\%)であった（表 3).

b. 嗅覚障害に対する臨床効果

嗅覚障害の改善を評価するため，治療前と後

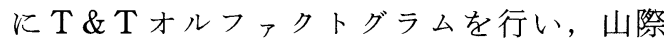
ら 13)の分類に従って判定した。. 認知域值平均 嗅力損失が50歳未満では 1 以下，50歳以上では 2 以下になった症例を治癒, 治癒には至らない が 1 以上変化した症例を軽快とし，両方を合わ せて改善としたＳ群では11例改善( 1 例治瘉, 10例軽快)， 7 例不変であった。C群では 1 例 軽快，5例不变であった(表 4 ).

また，自覚症状により，良好(注ぼニオイが わかる)，やや良好(少しは二オイがわかる)， 無効に分類した(表 5 )。汇ぼ T\& Tオルファ クトグラムによる結果と一致したが， S 群で, 不変症例 7 例のちち 1 例は良好， 2 例はやや良 好と申告した。C群では，1例の軽快症例も認 知域值平均嗅力損失は 1 改善したのみであり, 自覚的には不变であった。

表 $4 \mathrm{~T} \& \mathrm{~T}$ オルファクトグラムの改善

\begin{tabular}{c|c|c|c|c}
\hline \hline & 治癒 & 軽快 & 不変 & 改善率 \\
\hline “慢性副鼻腔炎” 症例 & 1 例 & 10 例 & 7 例 & $61 \%$ \\
\hline 対照症例 & 0 例 & 1 例 & 5 例 & $17 \%$
\end{tabular}

表 3 治療前の嗅覚障害の程度

\begin{tabular}{c|c|c}
\hline \hline & “慢性副畺腔炎’ 症例 & 対照症例 \\
\hline 中等度障害 $(2.6 \sim 4.1)$ & 2 例 & 0 例 \\
\hline 重度障害 $(4.1 \sim 5.6)$ & 6 例 & 2 例 \\
\hline 脱失 $\quad(5.6 \sim 5.8)$ & 10 例 & 4 例 \\
\hline 全体(m e a n \pm S.D) & 18 例 $(5.2 \pm 0.8)$ & 6 例 $(5.5 \pm 0.6)$
\end{tabular}


c . 副鼻腔炎に対する効果

$\mathrm{S}$ 群に括ける嗅覚障害以外の自覚症状につい ては，13例中 6 例は症状消失， 4 例は症状が軽 減した. 鼻漏・後鼻漏が改善しない症例が 2 例, 鼻漏と鼻閉とも改善しなかった症例が 1 例あっ たが，3 例とも嗅覚障害が改善しなかった症例 であった(表 6 ).

中鼻道に認められた鼻茸が消失した症例が 3 例あった. 2 例は嗅覚障害も改善した症例であ った。

鼻 X線では，嗅裂部については，閉鎖してい た13例中，12例が開大し，1例不変であった. 副鼻腔陰影は14例中, 5 例改善, 6 例不変, 3 例不明 $(3$ 例とも嗅覚障害不変例)であった(表 7 ).

\section{考察}

エリスロマイシン少量療法は, びまん性汎細 気管支炎に始まり, 副鼻腔気管支症候群, 更に 気管支病変を伴わない副鼻腔炎にも有効である 事が報告されている6) 99. またエリスロマイシ ン誘導体によっても同様である10) 12)。これら の報告によると, 鼻漏, 後鼻漏, 鼻閉, 頭痛・ 頭重感等は，自覚他覚症状とも $40 \%$ 70\%前後 改善している ${ }^{6) \sim 12)}$. 一方, 嗅覚障害に関して は，自覚症状の改善率は $30 \%$ 程度あるいはそれ 以下と低(6)7)10) 12), 本療法は鼻粘膜抒よび副 鼻腔粘膜の過分泌状態による症状, つまり鼻漏 や後鼻漏に対して効果が優れて扣り, 鼻粘膜の 腫脹や嗅覚障害に対しては, 手術療法が優先さ れると結論されている。しかし，今回我々が検 討を加えた '慢性副鼻腔炎” 症例では, その他 の症状と同様, 嗅覚障害も自覚的に $79 \%$, 他覚 的に $61 \%$ と高率に改善された。

我々の好成績の理由として, 対象症例の差が
まず考えられた，我々の症例は嗅覚障害を主訴 として扣り，また鼻X線に执いて，嗅裂部閉鎖

表 6 嗅覚障害以外の自覚症状の改善

\begin{tabular}{c|c|c|c|c}
\hline & 消失 & 軽減 & 不変 & 改善率 \\
\hline 重漏 ·後鼻漏 & 4 例 & 4 例 & 3 例 & $73 \%$ \\
\hline 鼻閉 & 3 例 & 0 例 & 1 例 & $75 \%$ \\
\hline 計 & 6 例 & 4 例 & 3 例 &
\end{tabular}

表 7 鼻X線の改善

\begin{tabular}{c|c|c|c}
\hline & 改善 & 不変 & 不明 \\
\hline 嗅裂部 & 12 例 & 1 例 & 0 例 \\
\hline 副鼾腔 & 5 例 & 6 例 & 3 例
\end{tabular}

表 8 背景因子別の改善率

\begin{tabular}{|c|c|c|c|}
\hline \multicolumn{2}{|c|}{ 背景因子 （症例数） } & 改善率 & $\chi^{2}$ 㭘定 \\
\hline \multirow{2}{*}{ 年齢 } & 50 歳末満（4） & $75 \%$ & \multirow{2}{*}{$\mathrm{n} \cdot \mathrm{s}$} \\
\hline & 50歳以上（14） & $57 \%$ & \\
\hline \multirow{2}{*}{ 罹病期間 } & 1 年未満 (8) & $75 \%$ & \multirow{2}{*}{ n. $\mathrm{s}$} \\
\hline & 1 年以上（10） & $50 \%$ & \\
\hline \multirow{2}{*}{ 性別 } & 男 （7） & $57 \%$ & \multirow{2}{*}{$\mathrm{n} \cdot \mathrm{s}$} \\
\hline & 女 (11) & $64 \%$ & \\
\hline \multirow{2}{*}{ 治療前嗅覚障害 } & 低下（8) & $63 \%$ & \multirow{2}{*}{ n. $\mathrm{s}$} \\
\hline & 脱失（10） & $60 \%$ & \\
\hline \multirow{2}{*}{\multicolumn{2}{|c|}{ 嗅覚障害以外の自覚症状 $\frac{\text { 有 (13) }}{\text { 無 }(5)}$}} & $43 \%$ & \multirow{2}{*}{$p<0.05$} \\
\hline & & $100 \%$ & \\
\hline \multirow{2}{*}{ 重X線 } & 腔院影あり (14) & $50 \%$ & \multirow{2}{*}{$\mathrm{p}<0.05$} \\
\hline & 部閉鎖のみ（4） & $100 \%$ & \\
\hline
\end{tabular}

表 9 嗅覚障害改善症例の鼻 $\mathrm{X}$ 線の変化

\begin{tabular}{c|c|c}
\hline \hline & 改善 & 不変 \\
\hline 嗅裂部 & 8 例 & 1 例 \\
\hline 副钼腔 & 2 例 & 5 例
\end{tabular}

表 5 嗅覚障害の自覚的改善

\begin{tabular}{c|c|c|c|c}
\hline \hline & 良好 & やや良好 & 無効 & 改善率 \\
\hline '慢性副重腔炎' 症例 & 11 例 & 3 例 & 4 例 & $78 \%$ \\
\hline 対照症例 & 0 例 & 0 例 & 6 例 & $0 \%$
\end{tabular}


のみで副鼻腔陰影を認めない症例も治療対象と した．そこでこの様な差が，改善率に影響する かどうか検討した（表 8 ）。嗅覚障害以外に副鼻 腔炎による自覚症状のない症例や，鼻X線で嗅 裂部閉鎖のみの症例は，有意に高率に改善し た $(\mathrm{p}<0.05)$.これらの症例は，これまでの報 告6)7)10) 12) では副鼻腔炎症例としての対象に は入って拉らず，よって我々の好成績に結びっ いたものと思われた. 尚, その他の背景因子(年 齢, 性, 罹病期間, 治療前嗅覚障害の程度)で は改善率には差を認めなかった。

$\mathrm{T} \& \mathrm{~T}$ オルファクトグラムで嗅覚障害の改 善を認めた11症例について，鼻X線の変化を検 討した．治療前に嗅裂部閉鎖を認めた 9 例のら ち 8 例が嗅裂部が改善した。一方, 穊骨洞およ び上顎洞に陰影を認めた 7 例のらち改善したも のは，2 例にとどまった(表 9 ).すすなわち，嗅 覚障害が改善した時点で，嗅裂部が閉鎖してい た症例は 1 例であったのに対して，副鼻腔陰影 を依然として認めた症例は 5 例めり，嗅覚には 嗅裂部の改善が重要であると思われた。エリス ロマインンは, 嗅裂部周辺の鼻粘膜に作用し, 嗅裂部を開大する事によって呼吸性嗅覚障害を 改善したものと推察された。咱裂部は解剖学的 に狭小であるため, 副鼻腔との効果の差がでた ものと思われる。

副鼻腔炎に合併した嗅覚障害では，嗅裂部が 開大している症例は，必ずしも呼吸性嗅覚障害 ではなく, 嗅粘膜障害を起こしている可能性が 考えられる.この様な症例にはェリスロマイシ ンは効果を示さないと推察される。従って，嗅 裂部粘膜の障害や改善の程度を知ることは極め て重要なことであるが，今回硬性鏡で嗅粘膜の 観察を行った症例は 6 例と少なく，嗅粘膜の状 態については不明であった，今後の検討が必要 と思われた。

\section{まとめ}

1）エリスロマイシン少量長期療法を，嗅覚 障害患者24名に対して行った。

2 ）鼻X線で, 副鼻腔あるいは嗅裂部に陰影
を認めた嗅覚障害患者18名では，自覚的に $79 \%$ ， $\mathrm{T} \& \mathrm{~T}$ オルファクトグラムで $61 \%$ の改善を認 めた。

3 ）嗅覚障害以外の鼻症状に対しても, 従来 の報告6) 9) と同様有効であった。

4 ）嗅神経以上が障害部位と思われる嗅覚障 害患者 6 名には, 本療法は無効であった。

5 ）嗅覚障害患者では，鼻 $X$ 線の嗅裂部の所 見が重要であると推察された。

\section{参考文献}

1）工藤翔二：びまん性沉細気管支炎。綜合臨床 $37: 11: 2628 \sim 2632,1988$.

2）工藤翔二：びまん性汎細気管支炎一エリスロ マイシン療法をめぐって一. 最新医学 $46: 107$ 〜18, 1991.

3）有木喜和, 武田博明, 小林宏行：マクロライド ・リンコマイシン系薬. 綜合臨床 $37: 2220$ $2224,1988$.

4）真崎美矢子, 道津安正, 増山泰治, 他 : マク口 ライド系抗生剤のヒト好中球内への移行に関す る研究. Chemotherapy 35:709〜713, 1987.

5）三上正志 : 慢性気道疾患の膿性痰中の Elastase (エリスロマイシンの臨床効果). 科学療法の領 域 $5: 19 \sim 24,1989$.

6) 菊地 茂, 山岨達也, 洲崎春海, 他 : 副鼻腔炎 とエリスロマイシン少量長期投与一第 2 報一. 耳鼻臨床 $85: 1245 \sim 1252,1992$.

7）高北晋一, 北村溥之, 大八木章博, 他：慢性副 鼻腔炎と少量エリスロマイシン療法. 耳鼻臨床 $84: 489 \sim 498,1991$.

8）小野幹夫，若盛和雄：難治性慢性副鼻腔炎に対 するエリスロマインンの長期投与の試み.耳展 $34: 639 \sim 645,1991$.

9）坂田 謙, 太田伸男, 深瀬 滋, 他：慢性副鼻 腔炎に対するエリスロマイシン少量長期投与 一臨床及び基礎的検討一。耳鼻免疫アレルギー $10: 132 \sim 133,1992$.

10）藤森俊也, 松岡 出, 中村 隆, 他 : 慢性副鼻 腔炎に対するルリッドの効果. 耳鼻臨床 85 : 761〜766, 1993.

11）宇野芳史, 斉藤龍介, 波多野篤, 他 : 副鼻腔炎 とロキシスロマイシン少量長期投与.耳鼻臨床 $86: 439 \sim 445,1993$. 
12）羽柴基之, 宮本直哉, 木村利男, 他 : 慢性副鼻 腔炎に対するエリスロマイシン誘導体(クラリ スロマイシン)の効果. 日本鼻化学会会誌 31 : 269 280, 1993.

13）山際幹和, 三吉康郎, 坂倉康夫, 他 : 当科嗅覚 外来の現況について, 耳鼻臨床 74 増2：938〜 947, 1981.
(原稿受付: 平成 6 年 4 月 14 日

原稿採択: 平成 6 年 5 月 24 日 急載 別刷請求先 : 島田久美

空5 540 大阪市中央区大手前1-5-34 大手前病院耳鼻咽喉科 